УдК 616.831-005.4:616.379-008.64]-019

DOI

\title{
ПОРУШЕННЯ ФУНКЦІОНАЛЬНОГО ТА МОРФОЛОГІЧНОГО СТАНУ СЛИННИХ ЗАЛОЗ ПРИ ЦУКРОВОМУ ДІАБЕТІ ТА ЇХ РОЛЬ В УШКОДЖЕННІ СЛИЗОВОЇ ОБОЛОНКИ РОТОВОї ПОРОЖНИНИ
}

\author{
ВДНЗ «Буковинський державний медичний університет», м. Чернівці
} діабет.

РЕЗЮМЕ. Проаналізовано сучасні дані стосовно механізмів ураження слинних залоз у хворих на цукровий КлючОВІ СлОВА: цукровий діабет, слинні залози.

Тривала гіперглікемія, спричиняючи множинні пошкодження органів і тканин, порушує також функцію слинних залоз, що призводить до зменшення слиновиділення та появи ксеростомії [1, 2, 3-9]. Остання, через підвищене злущення епітеліальних клітин, здатна спричинити низку змін у слизовій оболонці ротової порожнини: порушення мови та погіршання смакового сприйняття [6, 10]; високу схильність до поширення патогенних мікроорганізмів некандидозного характеру та інфекційні ускладнення $[7,8,11]$; розвиток орального кандидозу [11]; обкладений язик; неприємний запах із рота $[12,13]$; захворювання пародонта; демінералізацію зубів і появу білих плям [8, 14]; карієс, уповільнене загоєння ран; тріщини язика [15]; розвиток червоного плоского лишаю; виразки слизової оболонки $[16,17]$; слизові кисти, петехії, гіперкератоз і атрофію сосочків язика $[6,10]$; кутовий хейліт, гіперплазію ясен [8]. Найчастіше, за даними літератури, у хворих на цукровий діабет спостерігається варикозне розширення вен язика і еритематозний кандидоз [11-13].

Несприятливі наслідки зменшення кількості слини поглиблюються порушеннями ії̈ складу: підвищенням концентрації муцину і глюкози; змінами продукції та/або ефективності багатьох антимікробних факторів; відсутністю металопротеїну гастину, який містить цинк і відповідає за постійне дозрівання смакових сосочків $[8,9]$.

Доведено, що ці місцеві прояви тісно пов'язані з системними. Сьогодні немає жодного сумніву в існуванні взаємообумовленості в пацієнтів із цукровим діабетом патології слинних залоз, періодонтиту та ішемічної хвороби серця, впливу оральних патогенів на прогресування серцевосудинних захворювань [18, 19-21]. Виділені 3 атеросклеротичних бляшок коронарних артерій періодонтопатичні патогени підтверджують цей зв'язок [22]. Вважають, що ці мікроорганізми потрапляють у кровотік, прив'язуються до жирових бляшок на стінках коронарних артерій і сприяють утворенню тромбів. Ключову роль у цьому процесі відіграє uр-регуляція цитокінів та інших медіаторів запалення [18].

Патологія слинних залоз та пародонта у хворих на цукровий діабет збільшує ризик інших системних патологій: інфаркту, інсульту, респіраторних захворювань, у тому числі - пневмоній, остеопорозу і ураження суглобів [19-21, 23].

Не лише високий рівень цукру в крові обумовлює виникнення оральних ускладнень діабету та погіршує їх перебіг, а й захворювання слинних залоз і пародонта ускладнюють контроль глікемії $[24,25]$.

Оскільки у виникненні багатьох оральних ускладнень за умов діабету тригерним механізмом є порушення кількості і складу секретованої слини, характеристика морфофункціонального стану слинних залоз при даному захворюванні $\epsilon$ предметом уваги не лише стоматологів, але й діабетологів.

Інсулінозалежний цукровий діабет спричиняє суттєві зміни морфології слинних залоз, а відтак - і механізмів слиновиділення [26-29]. Частим проявом патології слинних залоз при діабеті $\epsilon$ сіалоз - збільшення, в основному, привушних залоз, яке, як правило, перебігає безсимптомно $[26,27$, 30]. При діабетичному сіалозі збільшення об'єму залоз пов'язане з жировою інфільтрацією паренхіми. Ці зміни виникають як в ацинарних клітинах, так і в клітинах вивідних проток [31]. Це захворювання при діабеті має дегенеративний характер і пов'язане зі зміною нервово-вегетативної регуляції залоз, демілієнізацією нервових волокон та наступною атрофією міоепітеліальних клітин. Воно порушує механізм секреції слини, який $є$ результатом стимуляції альфа- і бета-адренорецепторів ацинарних клітин, що фізіологічно спричиняє екзоцитоз, тому, як правило, виникає гіпосалівація і сухість у роті [32]. 
Огляди літератури, оригінальні дослідженн, погляд на проблему

Світлооптичне дослідження і скануюча електронна мікроскопія привушних і підщелепних залоз мишей із генетичною схильністю до діабету (лінії Nod) показали атрофічні зміни ядер і цитоплазми, дезорганізацію біомембрани, зростання фібрилярних компонентів позаклітинного матриксу і наявність клітин у стані запалення [33]. Інсулінотерапія має позитивний вплив на відновлення цих змін, проте не усуває їх повністю [34, 35]. Автори вважають, що така деструктуризація слинних залоз призводить до змін функціональних показників останніх.

Зроблено спроби визначення білкових біомаркерів ксеростомії діабетичного походження в слині. На моделі мишей із ксеростомією ідентифікували різницю експресії генів привушної залози мишей без діабету, тих, що страждають на ожиріння та мишей із діабетом із подальшим дослідженням експресії білків, кодованих цими генами, в привушній залозі і слині. Встановлено, що експресія хітинази була більш суттєвою в клітинах привушних ацинарних клітин мишей із діабетом, порівняно з іншими двома групами. Таким чином, підвищена експресія хітинази і активність відповідних ферментів можуть характеризувати автоімунний діабет у мишей, однак необхідні подальші дослідження, щоб оцінити використання цих показників в якості біомаркерів ксеростомії в людини [36].

Взаємозв'язок високої поширеності захворювань порожнини рота у хворих на цукровий діабет із порушенням слиновиділення сьогодні пов'язують зі змінами вмісту в слині деяких біологічно активних речовин. Зокрема, це слинні білки, необхідні для збереження цілісності зубів $[37,38]$. Серед них провідну роль відводять статеринам - білкам слини, що беруть участь в утворенні плівки емалі і регуляції гомеостазу кальцію. Цукровий діабет впливає як на слиновиділення, так і на секрецію білків слинних залоз, що призводить до підвищеної сприйнятливості до інфекцій слизових, демінералізації зубів і карієсу [39]. Статерини виділяють як великі, так і малі слинні залози [40]. Проведення імуногістохімічних досліджень із використанням моноклональних антитіл підтвердило, що в підщелепній, привушній та малих губних залозах хворих на діабет експресія статеринів знижена [41].

Вивчення природи і механізмів розвитку ксеростомії протягом останніх років дозволило виявити низку молекулярних механізмів, відповідальних за це явище. Одним із таких механізмів $\epsilon$ порушення внутрішньоклітинної локалізації в слинних залозах аквапорину-5 (AQP5) та експресії білка AQP5 [42]. Проведені дослідження показали, що незважаючи на збільшення MPHK AQP5, уміст білка AQP5 у привушній залозі хворих на цукровий діабет був знижений, порівняно з контролем. Автори вважають, що відсутність транслокації AQP5 у слинні залози у відповідь на мускаринові агоністи і пригнічення експресії білка AQP5 може призвести до діабетичної ксеростомії.

Інший можливий механізм ксеростомії вбачають у порушенні експресії гена SLC5A1, який кодує Na (+)-глюкозокотранспортер SGLT1 - білок, який переносить не тільки глюкозу, але також діє як канал для води [43]. Показано, що зниження слиновиділення, спричинене діабетом, супроводжується підвищеною експресію MPHK SGLT1 у привушних і підщелепних залозах. Збільшення внаслідок цього вмісту білка SGLT1 в люменальній мембрані клітин вивідних проток, за рахунок збільшення реабсорбції води, може сприяти викликаному діабетом зниженню слиновиділення. Крім того, білок SGLT1 був зниженим у міоепітеліальних клітинах привушних залоз діабетичних тварин, тому слиновиділення може бути зменшене також за рахунок зниження скорочувальної активності клітин. Шестиденне призначення інсуліну таким щурам приводило до оборотного розвитку всіх змін. Більш пізніми дослідженнями авторів показано, що діяльність SGLT1 плазмових мембран регулюється симпатичною нервовою системою через протеїнкіназу А [44].

Багато досліджень проведено для характеристики біохімічних змін слини хворих на цукровий діабет. Ці зміни стосуються концентрації глюкози, загального білка, альбуміну, лізоциму, пероксидази, електролітів (натрію, калію, хлору, фосфору, магнію і кальцію), амілази, IgA та буферної ємності [45-48]. Знайдено збільшення рівнів сечовини та загального білка і зниження рівня мікроальбуміну в слині хворих на цукровий діабет, хоча ніяких істотних змін не було виявлено в концентрації амілази, натрію, калію і хлориду $[49,50]$. За іншими ж даними ці результати можуть відрізнятися в різних групах хворих $[51,52]$.

Як зазначалося, зазвичай у хворих на діабет слиновиділення знижене, що призводить до ксеростомії. Однак у хворих із діабетичною автономною нейропатією слиновиділення значно підвищене, що не має достовірних пояснень, хоча існує точка зору, що це $\epsilon$ результатом втрати гальмівних нейронних механізмів $[5,53]$.

У порушенні функцій слинних залоз при діабеті важлива роль належить модифікаціям імунного статусу. Виходячи з цього робляться спроби доповнити або замінити інсулінотерапію імунотерапією. Оцінка ефективності анти-CD3 моноклональних антитіл в якості альтернативної імунотерапії для відновлення слинних залоз спонтанно діабетичних щурів показала, що зміни цитоархі- 
Огляди літератури, оригінальні дослідження, погляд на проблему

тектоніки, потовщення позаклітинного матриксу та запальний процес у залозах таких щурів значно зменшуються під впливом такої імунотерапії [26].

Первинні пошкодження слинних залоз, спричинені гіперглікемією, поглиблюються за рахунок змін рівнів інших гормонів та порушення їх взаємодії з клітинними рецепторами при прогресуванні діабету [34]. Оцінка впливу замісної терапії естрогенами в поєднанні з інсуліном для корекції морфофункціонального стану слинних секреторних клітин і експресії в них інсуліноподібного фактора росту (IGF) спонтанно діабетичних (NOD) мишей виявила реструктуризацію тканин залози і регулювання експресії рецепторів IGF-I під впли-

\section{ЛITEPATУPA}

1. Radhika T. Diabetes mellitus and oral health / T. Radhika, R. Kannan // J. Orofac. Sci. - 2012. - Vol. 4, Iss. 1. P. 7-10.

2. Sousa M.G. Clinical study of the oral manifestations and related factors in type 2 diabetics patients / M. G. Sousa, L. Costa Ade, A.G. Roncalli // Braz. J. Otorhinolaryngol. 2011. - Vol. 77, № 2. - P.145-152.

3. Xerostomia and hyposalivation: a preliminary report of their prevalence and associated factors in Brazilian elderly diabetic patients / B. C. Borges, G. M. Fulco, A. J. Souza // Oral Health Prev. Dent. - 2010. - Vol. 8, № 2. - P. 153-158.

4. Type 1 diabetes mellitus, xerostomia, and salivary flow rates / P. A. Moore, J. Guggenheimer, K. R. Etzel [et al.] // Oral Surg. Oral Med. Oral Pathol. Oral Radiol. Endod. - 2001. - Vol. 92, № 3. - P. 281-291.

5. Moore P. A. Burning mouth syndrome and peripheral neuropathy in patients with type 1 diabetes mellitus / P. A. Moore, J. Guggenheimer, T. Orchard // J. Diabet. Complications. - 2007. - Vol. 21, № 6. - P. 397-402.

6. Effects of diabetes mellitus on salivary secretion and its composition in the human / A. D. Mata, D. Marques, S. Rocha [et al.] // Mol. Cell. Biochem. - 2004. - Vol. 261, № 1. - P. 137-142.

7. Xerostomia, hyposalivation, and oral microbiota in type 2 diabetic patients: a preliminary study / S. O. Khovidhunkit, T. Suwantuntula, S. Thaweboon, S. Mitrirattanakul // J. Med. Assoc. Thai. - 2009. - Vol. 92, № 9 .- P. 1220-1228.

8. Negrato C. A. Buccal alterations in diabetes mellitus / C. A. Negrato, O. Tarzia // Diabetol. Metab. Syndr. -2010. - Vol. 2, № 3. 10.1186/1758-5996-2-3/

9. Mese H. Salivary secretion, taste and hyposalivation / H. Mese, R. Matsuo // J. Oral Rehabil. -2007. - Vol. 34, № 10. - P. 711-723.

10. Oral mucosa symptoms, signs and lesions, in end stage renal disease and non-end stage renal disease diabetic patients / E. de la Rosa García, A. Mondragón Padilla, S. Aranda Romo, M. A. Bustamante Ramírez // Med. Oral Patol. Oral. Cir. Bucal. - 2006. - Vol. 11, № 6. - P. 467-473.

11. Comparison of maxillofacial space infection in diabetic and nondiabetic patients / D. D. Rao, A. Desai, R. D. Kulkarni [et al.] // Oral Surg. Oral Med. Oral Pathol. Oral Radiol. Endod. - 2010.- Vol. 110, № 4. - P. 7-12. вом такої замісної терапії. Естрогени сприяють ефективному відновленню слинних секреторних клітин, демонструючи, що цей гормон сам, і особливо в поєднанні з інсуліном, може мати важливе значення для реверсії пошкодження тканин гіперглікемією.

Результати наукових доробків, наведених у даному огляді, свідчать про перспективність подальших досліджень механізмів порушення морфофункціонального стану слинних залоз за умов цукрового діабету та їх взаємозв'язку з іншими ускладненнями даної патології для пошуку нових патогенетично обґрунтованих методів впливу на перебіг даного страждання.

12. Al-Attas S. A. Candidal colonization, strain diversity, and antifungal susceptibility among adult diabetic patients / S. A. Al-Attas, S. O. Amro // Ann. Saudi Med. 2010. - Vol. 30, № 2. - P. 101-108.

13. Oral Health Knowledge and Behavior among Adults with Diabetes / H. Yuen, J. Wolf Bethany, D. Bandyopadhyay [et al.] // Diabetes Res. Clin. Pract. - 2009. Vol. 86, № 3. - P. 239-246.

14. Knowledge and awareness about diabetes and periodontal health among Jordanians / R. Al Habashneh, Y. Khader, M. M. Hammad, M. Almuradi // J. Diabetes Complications. - 2010. - Vol. 24, № 6. - P. 409-414.

15. Abiko Y. The mechanism of protracted wound healing on oral mucosa in diabetes Review / Y. Abiko, D. Selimovic // Bosn. J. Basic Med. Sci. - 2010. - Vol. 10, № 3. - P. 186-191.

16. Oral mucosal lesions in non oral habit diabetic patients and association of diabetes mellitus with oral precancerous lesions / R. Sainia, S. Ali Al-Maweria, D. Sainib [et al.] // Diabetes Res.Clin. Practice. - 2010. - Vol. 89, Iss. 3. P. 320-326.

17. Clinical features of oral lichen planus - a retrospective study of 65 cases / E. Torrente-Castells, R. Figueiredo, L. Berini-Aytés, C. Gay-Escoda // Med. Oral Patol. Oral. Cir. Bucal. - 2010. - Vol. 15, № 5. - P. 685-690.

18. Al-Maskari Awatif Y. Oral Manifestations and Complications of Diabetes Mellitus / Y. Awatif Al-Maskari, Y. Masoud Al-Maskari, Salem Al-Sudairy // Sultan Qaboos Univ. Med. J. - 2011. - Vol. 11, № 2. - P. 179-186.

19. Kuo L. Associations between periodontal diseases and systemic diseases: A review of the inter-relationships and interactions with diabetes, respiratory diseases, cardiovascular diseases and osteoporosis / L. Kuo, A. M. Polson, T. Kang // Public Health. - 2008.- Vol. 122, № 4. P. 417-433.

20. Davies R. M. Periodontal disease and general health / R. M. Davies, G. M. Davies // Dent. Update. 2005. Vol. 32, № 8.- P. 438-402.

21. tal disease and systemic disease: evaluating the strength of the evidence / T. Dietrich, R. I. Garcia // J. Periodontol. - 2005. - Vol. 76, № 11. P. 2175-2184. 
22. Correlation between atherosclerosis and periodontal putative pathogenic bacterial infections in coronary and internal mammary arteries / A. Pucar, J. Milasin, V. Lekovic [et al.] //J. Periodontol. - 2007. - Vol. 78, № 4. P. 677-682.

23. Oral health in Thai patients with metabolic syndrome / U. Chomkhakhai, S. Thanakun, S.-P. Khovidhunkit [et al.] // Diabetes Metab. Syndr. - 2009. - Vol. 3, Iss. 4. P. 192-197.

24. Teeuw W. J. Effect of periodontal treatment on glycemic control of diabetic patients: A systemic review and meta-analysis / W. J. Teeuw, V. E. A. Gerdes, B. G. Loos // Diabetes Care. - 2008. - Vol. 33, № 2. - P. 421-427.

25. Efficacy of periodontal treatment on glycaemic control in diabetic patients: A meta-analysis of interventional studies / L. Darr, J. N. Vergnes, P. Gourdy, M. Sixou // Diabetes Metab. - 2008. - Vol. 34, № 5. - P. 497-506.

26. Structural and functional salivary disorders in type 2 diabetic patients / C. Carda, N. Mosquera-Lloreda, L. Salom [et al.] // Med. Oral Patol. Oral Cir. Bucal. - 2006. Vol. 11, № 4. - P. 309-314.

27. Sialography: report of 3 cases / S. S. Reddy, N. Rakesh, N. Raghav, D. Devaraju // Indian J. Dent. Res. 2009. - Vol. 20, № 4. - P. 499-502.

28. The influence of type-1 diabetes mellitus on dentition and oral health in children and adolescents / R. Orbak, S. Simsek, Z. Orbak [et al.] // Med. J. - 2008. - Vol. 49, № 3. - P. 357-365.

29. Особенности ГРВ биоэлектрографии секретов больших слюнных желез у больных сахарным диабетом / О. В. Мячина, А. А. Зуйкова, А. Н. Пашков, [и др.] // Успехи современного естествознания. - 2012. - №7. C. $46-49$

30. Ionic and histological studies of salivary glands in rats with diabetes and their glycemic state after laser irradiation / A. Simões, E. de Oliveira, L. Campos, J. Nicolau // Photomed. Laser Surg. - 2009. Vol. 27, № 6. - P. 877-883.

31. Functional and molecular characterization of the fluid secretion mechanism in human parotid acinar cells / T. Nakamoto, A. Srivastava, V. G. Romanenko [et al.] // Am. J. Physiol. Regul. Integr. Comp. Physiol. - 2007. - Vol. 292, № 7. - P. 2380-2390.

32. Slezák R. Xerostomia, hyposialia, sicca syndrome quantitative disturbances of the salivary flow rate / R. Slezák, I. Berglová, J. Krejsek // Vnitr. Lek. -2011. - Vol. 57, № 4. - P. 339-346.

33. Stereology and ultrastructure of the salivary glands of diabetic Nod mice submitted to long-term insulin treatment / E. J. Caldeira, J. A. Camilli, V. H. Cagnon // Anat Rec. Discov. Mol. Cell. Evol. Biol. - 2005. - Vol. 286, № 2. - P. 930-937.

34. Yashida M. H. Estrogen and insulin replacement therapy modulates the expression of insulin-like growth factor-I receptors in the salivary glands of diabetic mice / M. H. Yashida, A. L. Da Silva Faria, E. J. Caldeira // Anat. Rec. - 2011. - Vol. 294, № 11. - P. 1930-1938.

35. Recovery of INS-R and ER-alpha expression in the salivary glands of diabetic mice submitted to hormone replacement therapy / E. T. Maekawa, E. E. Maioral, H. T. Metidieri [et al.] // Arch. Oral Biol. - 2011. - Vol. 56, № 10. - P. 1129-1136.
36. Chitinase expression in parotid glands of nonobese diabetic mice / T. Fukushima, T. Nashida, M. HagaTsujimura, I. Mataga // Oral Dis. - 2012 - Vol. 18, № 5. P. 506-512.

37. Amerongen A. Van Nieuw. Salivary proteins: protective and diagnostic value in cariology? / A. Van Nieuw Amerongen, J. G. Bolscher, E. C. Veerman // Caries Res. 2004. - Vol. 38, № 3. - P. 247-253.

38. Salivary peptidome in type 1 diabetes mellitus / A. Caseiro, R. Vitorino, A. S. Barros, R. Ferreira // Biomed. Chromatogr. - 2012.- Vol. 26, № 5. - P. 571-582.

39. Reduced statherin reactivity of human submandibular gland in diabetes / M. Isola, P. Solinas, E. Proto [et al.] // Oral Dis.- 2011.- Vol. 17, № 2. P. 217-220.

40. Diabetes affects statherin expression in human labial glands / M. Isola, M. Lantini, P. Solinas [et al.] // Oral Dis. - 2011. - Vol. 17, № 7. - P. 685-689.

41. Diabetes reduces statherin in human parotid: immunogold study and comparison with submandibular gland / M. Isola, M. Cossu, M. Diana, R. Isola // Oral Dis. 2012. - Vol. 18, № 4. - P. 360-364.

42. Abnormal subcellular localization of AQP5 and downregulated AQP5 protein in parotid glands of streptozotocin-induced diabetic rats / D. Wang, Z. Yuan, N. Inoue, G. Cho // Biochim. Biophys. Acta. - 2011.Vol. 1810, № 5.- P. 543-554.

43. Na+-glucose cotransporter SGLT1 protein in salivary glands: potential involvement in the diabetes-induced decrease in salivary flow / R. Sabino-Silva, H. S. Freitas, M. L. Lamers [et al.] // J. Membr. Biol. - 2009. - Vol. 228, № 2. - P. 63-69.

44. SGLT1 protein expression in plasma membrane of acinar cells correlates with the sympathetic outflow to salivary glands in diabetic and hypertensive rats / R. Sabino-Silva, A. B. Alves-Wagner, K. Burgi, M. M. Okamoto [et al.] // Am. J. Physiol. Endocrinol. Metab. - 2010. - Vol. 299, № 6. - P. 1028-1037.

45. Зубачик В. М. Місцева гуморальна протибактеріальна резистентність у хворих на генералізований пародонт / В. М. Зубачик, М.В.Ліснічук, Г. О. Потьомкіна // Соврем. стоматол. - 2009. - № 1. - С. 38-42.

46. Изменение кислотно-основного равновесия в полости рта под влиянием местного лечения у больных пародонтитом и сопутствующим сахарным диабетом 2 типа / Е. В. Битюкова, В. А. Румянцев, К. А. Коротеев [и др.] // Стоматология для всех. - 2008. - № 3. - С. 10-14.

47. Amylase and cyclic AMP receptor protein expression in human diabetic parotid glands / M. Piras, A. R. Hand, M. I. Mednieks, M. Piludu // J. Oral. Pathol. Med. - 2010. Vol. 39, № 9. - P. 715-721.

48. Salivary glucose concentrations in patients with diabetes mellitus - a minimally invasive technique for monitoring blood glucose levels / S. Amer, M. Yousuf, P. Q. Siddiqiui, J. Alam // Pak. J. Pharm. Sci. - 2001. - Vol. 14, № 1. P. 33-37.

49. Periodontal disease and type 2 diabetes: Effects on salivary enzyme activities / E. J. Ikekpeazu, E. E. Neboh, I. C. Maduka [et al.] // Int. J. Diabetes Dev. Ctries. - 2011. Vol. 31, № 1. - P. 9-13.

50. Specific expression of salivary maxi-K channel variant is augmented in diabetic mice / K. Okamura, K. Kato, 
Огляди літератури, оригінальні дослідження, погляд на проблему

R. Uchida, T. Ohkubo // Arch. Oral. Biol. - 2010. - Vol. 55, № 11. - P. 848-854.

51. Collagenases in gingival crevicular fluid in type 1 diabetes mellitus / B. Safkan-Seppälä, T. Sorsa, T. Tervahartiala, A. Beklen [et al.] // J. Periodontol. - 2006. - Vol. 77, № 2. - P. 189-194.

52. Proteomic identification of salivary biomarkers of Type-2 diabetes / P. A. Rao, A. P. Reddy, X. Lu [et al.] // J. Proteome Res. - 2009. - Vol. 8, № 1. - P. 239-245.
53. Sandberg G.E. Oral dryness and peripheral neuropathy in subjects with type 2 diabetes / G. E. Sandberg, K. F. J. Wikblad // Diabet. Complications. - 2003. - Vol. 17, № 4. - P. 192-198.

54. Effects of anti-CD3 monoclonal antibody in salivary glands of spontaneously diabetic mice / $\mathrm{H}$. T. Metidieri, R. D. Mancio, É. E. Mayoral [et al.] // Microsc. Res. Tech. - 2012. - Vol. 75, № 7. - P. 928-934.

\title{
MECHANISMS OF DISORDERS OF THE FUNCTIONAL AND MORPHOLOGICAL CONDITION OF SALIVARY GLANDS IN CASE OF DIABETES MELLITUS AND THEIR ROLE IN ORAL MUCOSA LESIONS
}

@A. A. Halahdyna

\author{
HSEI «Bukovynian State Medical University», Chernivtsi
}

SUMMARY. Up to-date data concerning mechanisms of salivary glands destruction in case of diabetes mellitus has been analyzed.

KEY WORDS: diabetes mellitus, salivary glands. 